\title{
Mapping the child health system at a local level to reduce health inequalities
}

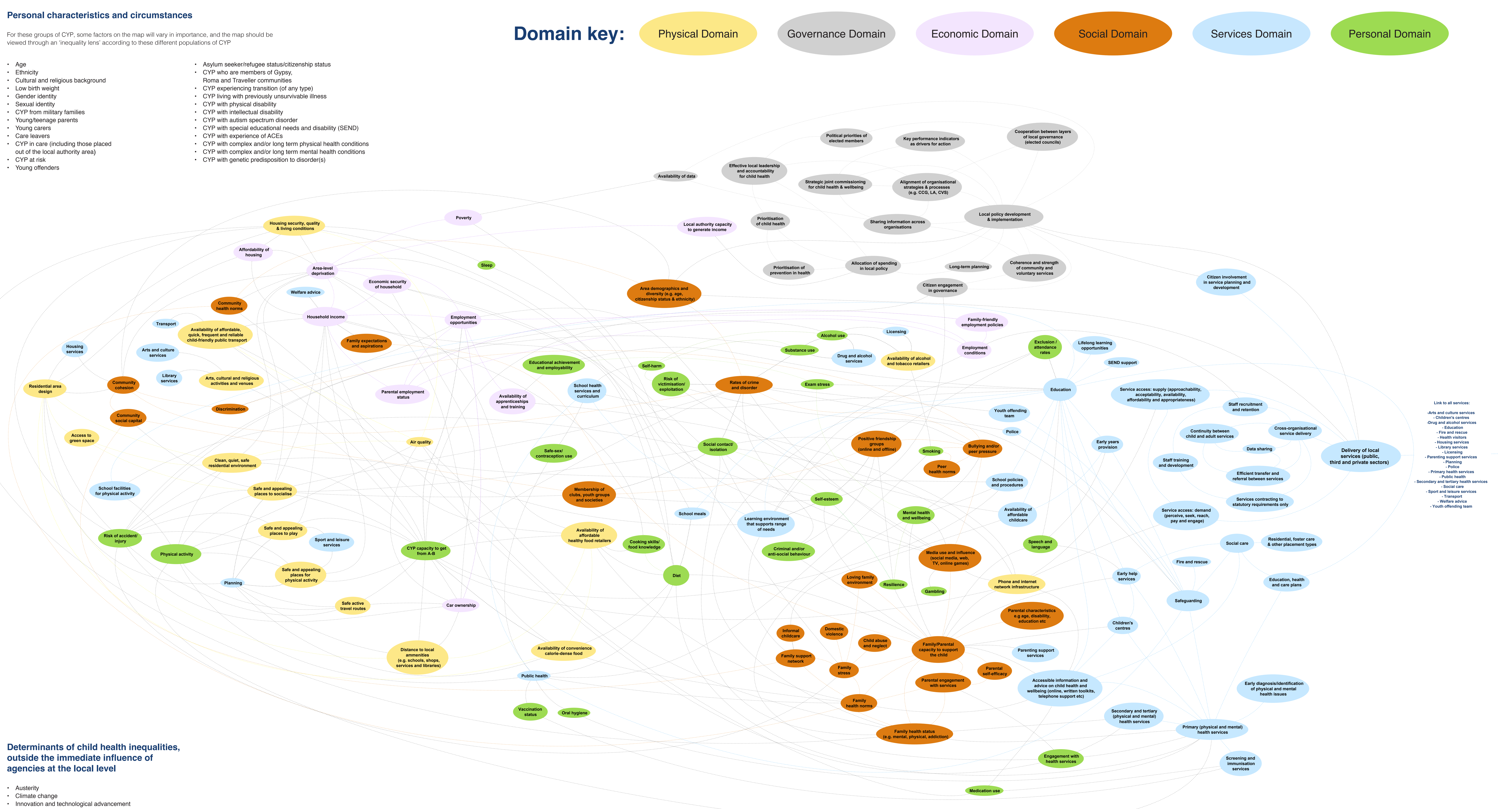

